\title{
Mutasi Isocitrate Dehydrogenase 1 dan 2 pada Glioma
}

\section{Ni Putu Sriwidyani*}

Departemen Patologi Anatomi Fakultas Kedokteran Universitas Udayana.

*Penulis korespondensi: sriwidyani@unud.ac.id.

\section{ABSTRAK}

Klasifikasi tumor sistem saraf pusat WHO terakhir didasarkan atas histogenesis tumor dan karakteristik molekuler genetik. Perubahan klasifikasi yang paling signifikan terjadi pada tumor glioma difus yang paling signifikan, yaitu katagori tumor secara garis besar berdasarkan status mutasi isocitrate dehydrogenase (IDH) 1 dan 2. Tulisan ini akan membahas tentang IDH1 dan IDH baik normal maupun mutan, hubungan mutasi IDH1 dan IDH2 dengan prognosis pasien, serta bagaimana penentuan status mutasi IDH1 dan IDH2 dalam diagnosis glioma.

Kata kunci: glioma, IDH, isocitrate dehydrogenase, mutasi.

DOI: https://doi.org/10.24843/JBN.2021.v05.i01.p05

\section{ABSTRACT}

The latest WHO central nervous system classification is based on tumor histogenesis and genetic molecular characteristics. The most significant classification change is in diffuse gliomas, which is tumor categorization mainly based on isocitrate dehydrogenase (IDH) 1 and 2 mutation status. This review will be described about normal and mutant IDH1 and IDH2, correlation between IDH mutation status with prognosis, and how to determine IDH1 and IDH2 mutation status in diagnosis of gliomas.

Keywords: glioma, IDH, isocitrate dehydrogenase, mutation.

\section{PENDAHULUAN}

Glioma merupakan tumor sistem saraf pusat (SSP) tersering, terutama pada dewasa. Pada klasifikasi tumor SSP tahun 2016, Klasifikasi tumor SSP mengintegrasikan gambaran morfologi dan molekuler. Di samping berdasarkan gambaran histologik, tumor glioma difus pada dewasa diklasifikasikan berdasarkan status mutasi gen isocitrate dehydrogenase (IDH), p53 dan alpha thalassemia/mental retardation syndrome $x$-linked (ATRX), serta adanya kodelesi 1p/19q. ${ }^{1}$ Pemahaman tentang genetik molekuler pada glioma menjadi dasar klasifikasi tumor, serta penentuan prognosis dan pilihan terapi pasien glioma. ${ }^{2}$
IDH merupakan suatu enzim yang berperan pada siklus tricarboxylic acid (TCA) yang penting dalam metabolisme energi. IDH mutan akan menghasilkan metabolit 2hydroxyglutaric acid (2-HG) yang tampaknya berperan pada gliomagenesis pada kasus glioma difus dengan IDH mutan. ${ }^{3,4,5}$ Mutasi IDH dijumpai pada lebih dari $70 \%$ kasus glioma difus grade II/III dan glioblastoma sekunder. ${ }^{6,7}$

Tulisan ini akan membahas tentang IDH1 dan IDH2 normal dan mutan, serta implikasi pemeriksaan status IDH1 dan IDH2 pada diagnosis terintegrasi pada glioma. 


\section{IDH1 DAN IDH2}

IDH pada manusia terdapat dalam tiga isoform, yaitu IDH1, IDH2, dan IDH3. IDH1 (terdapat di sitoplasma dan peroksisom) dan IDH2 (terdapat di matriks mitokondria) merupakan nicotinamide adenine dinucleotide phosphate $\left(N A D P^{+}\right)$-dependent. $\quad$ Enzim homodimer ini mengkatalisir reaksi redox yang mengkonversi isocitrate menjadi $\alpha$ ketoglutarate $(\alpha-\mathrm{KG})$ saat mereduksi NDP menjadi NADPH dan melepaskan $\mathrm{CO} 2$. Enzim IDH1 dan IDH2 berperan pada metabolism karbohidrat, asam lemak, dan glutamate, serta berkontribusi dalam menjaga status redox seluler normal. ${ }^{3}$

Mutasi pada gen IDH1 dan IDH2 yang menyandi protein IDH1 dan IDH2 akan menghasilkan protein mutan yang menginhibisi aktifitas enzim normal. Di samping itu, enzim IDH mutan memiliki aktifitas neomorfik yang akan mengkonversi $\alpha-\mathrm{KG}$ menjadi $2-\mathrm{HG}^{3}{ }^{3}$

\section{MUTASI IDH1 DAN IDH2 PADA GLIOMA}

IDH1 dan IDH2 terlibat dalam tumorigenesis beberapa jenis keganasan seperti glioma, leukemia myeloid akut, limfoma, kolangiokarsinoma intrahepatik, dan kondrosarkoma. ${ }^{2}$ Pada glioma difus, mutasi IDH ini tampaknya berperan pada proses awal tumorigenesis pada sebagian besar kasus glioma grade II dan III, serta sebagian kasus glioblastoma sekunder.

Penelitian oleh Parsons dkk. (2008) merupakan yang pertama kali megidentifikasi adanya mutasi IDH1 pada 12\% sampel kasus glioblastoma yang diteliti. Penelitianpenelitian selanjutnya menunjukkan adanya mutasi IDH1 dan IDH2 pada $70-90 \%$ kasus glioma grade II-III dan glioblastoma sekunder. Mutasi IDH1 yang dijumpai adalah missense mutation pada satu asam amino pada arginine
132 (R132) sedangkan mutasi pada IDH2 pada asam amino arginine 172 (R172). ${ }^{8}$

Pada tumorigenesis glioma, diduga mutasi gen yang menyandi IDH1 dan IDH2 akan menghasilkan protein mutan (2-HG) yang dapat menginhibisi diferensisi sel punca glioma, menimbulkan upregulasi vascular endothelial growth factor (VEGF) yang akan memicu pembentukan lingkungan mikro tumor, dan meningkatkan level hypoxiainducible factor- $1 \alpha$ (HIF-1 $\alpha){ }^{9}$ Mutasi IDH tampaknya merupakan proses onkogenik awal pada gliomagenesis, dimana mutasi-mutasi lanjutan merupakan proses penting yang berkontribusi terhadap pembentukan tumor.

\section{STATUS IDH DAN DIAGNOSIS GLIOMA MENURUT KLASIFIKASI WHO TAHUN 2016}

Klasifikasi tumor saraf pusat WHO sejak edisi pertama sampai keempat didasarkan atas konsep histogenesis dengan mengevaluasi morfologi tumor untuk menilai dari sel mana tumor berasal. Dengan banyaknya penelitian molekuler yang meningkatkan pengetahuan tentang perubahan genetik yang mendasari tumorigenesis tumor SSP, maka klasifikasi tumor SSP terbaru (WHO edisi keempat (update) tahun 2016) mengintegrasikan gambaran histologik dan molekuler dalam klasifikasi tumor SSP.

Pada klasifikasi tumor SSP edisi sebelumnya, glioma difus pada dewasa diklasifikasikan menjadi tumor astrositik, oligodendroglial, dan oligoastrositik. Pada edisi tahun 2016, di samping berdasarkan gambaran histologik tumor, klasifikasi juga didasarkan atas berdasarkan perubahan genetik yaitu status mutasi IDH, p53 dan ATRX, serta adanya ko-delesi 1p/19q (Gambar 1). ${ }^{1}$ 


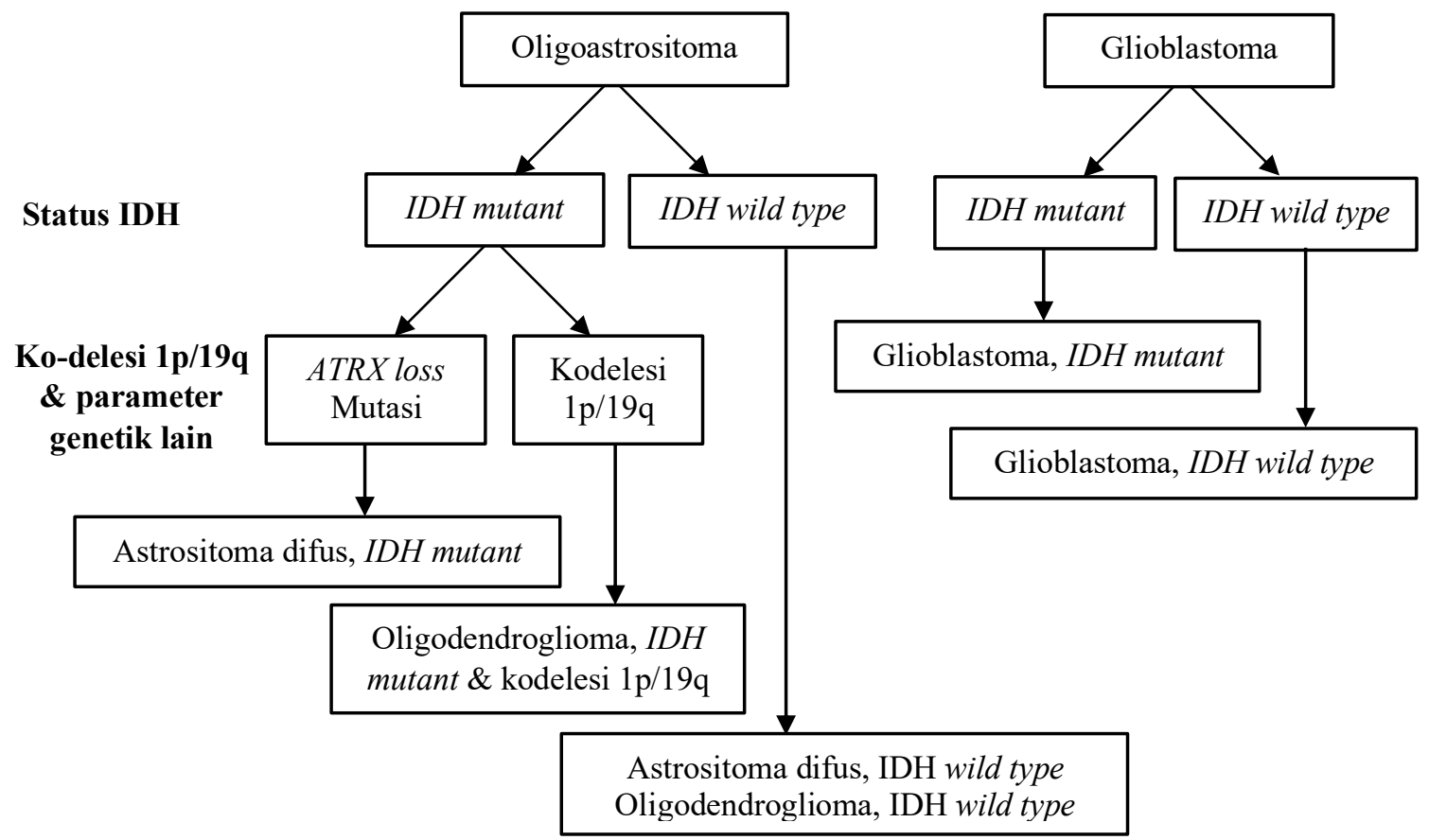

Gambar 1. Algoritme klasifikasi glioma difus berdasarkan gambaran histologik dan genetik. ${ }^{1}$
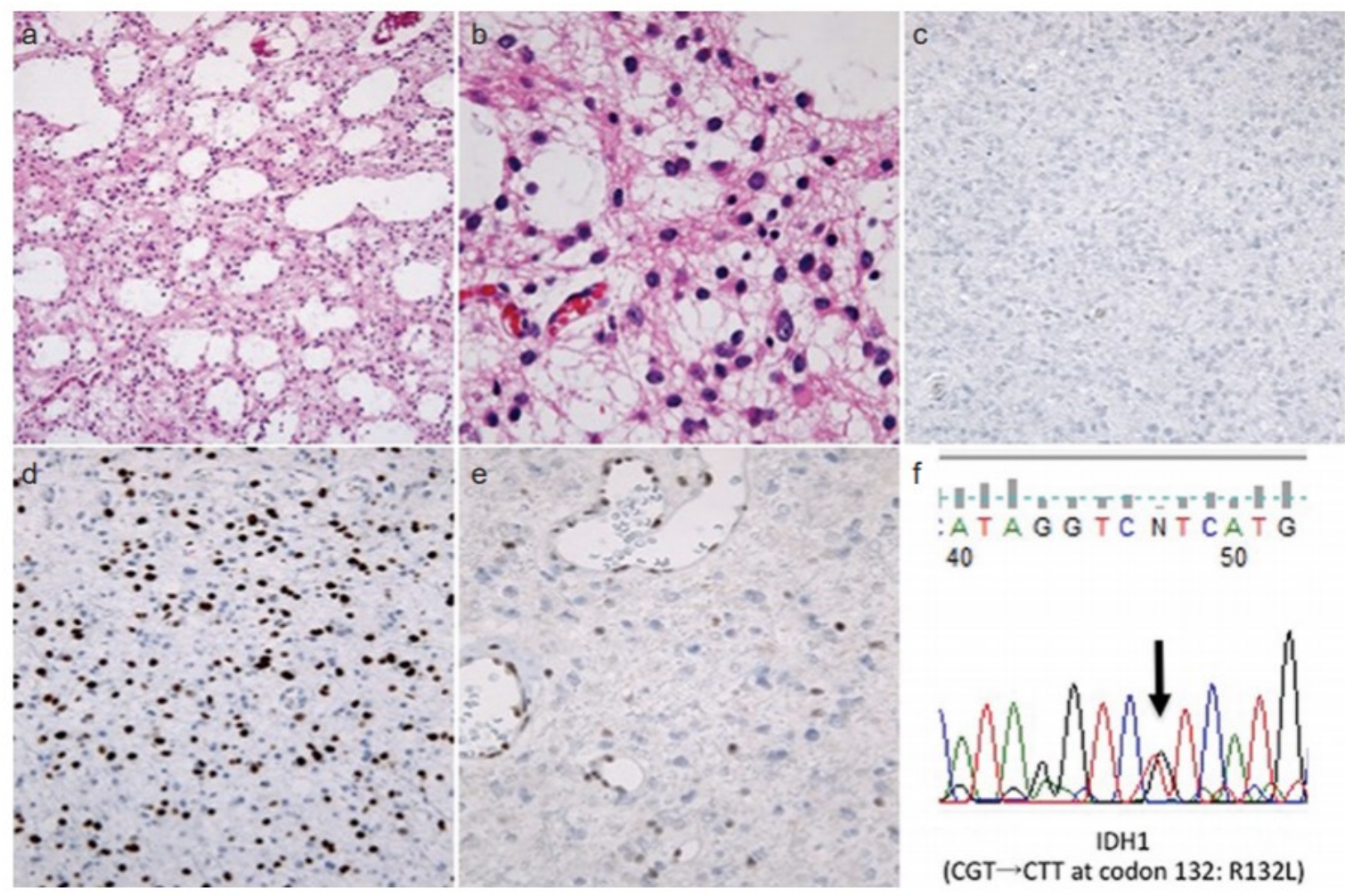

Gambar 2. Anaplastic astrocytoma, WHO 2016. (a) Inti sel berbentuk oval relatif uniform dengan latar belakang mikrokistik. (b) Pada pembesaran tinggi, beberapa inti telanjang tanpa prosesus sitoplasma, sementara sebagian lainnya menunjukkan prosesus fibriler, inti sel menunjukkan iregularitas dan hiperkromasia. Gambaran ini sesuai untuk anaplastic astrocytoma. (c) Imunohistokimia IDH1 R132H negatif. (d) p53 positif difus. (e) Imunoreaktivitas ATRX hilang pada sel tumor tetapi intak pada sel endotel. (f) Karena p53 positif dan ATRX negatif, kasus cenderung dengan mutasi IDH. Sanger sequencing menunjukkan adanya mutasi IDH1 R132L. ${ }^{11}$ 
Pada WHO 2016, evaluasi sediaan konvensional H\&E tetap merupakan stratifikasi awal. Setelah menentukan kategori mayor (seperti infiltrating glioma, neuronal tumor, atau embryonal tumor) berdasarkan histologik, kemudian dilanjutkan dengan hasil pemeriksaan molekuler. Terdapat status "not otherwise specified (NOS)" untuk kasus dimana pemeriksaan genetik tidak tersedia, pemeriksaan genetik tidak menunjukkan gambaran alterasi genetik yang sesuai dengan temuan histologik, atau jika terdapat keterbatasan evaluasi karena sampel jaringan yang insufisien atau terdapat artefak jaringan. ${ }^{10}$

Integrasi pemeriksaan molekuler di atas pada pemeriksaan histologik konvensional memberikan jalan keluar pada masalah yang cukup sering dijumpai pada diagnosis glioma berdasarkan evaluasi morfologi. Evaluasi sediaan H\&E pada kasus glioma sering sulit membedakan antara astrositoma grade II dengan grade III karena kesulitan membedakan selularitas, derajat atipia, dan tidak adanya cut-off jumlah mitosis. Kesulitan lainnya adalah dalam membedakan glioma dengan lesi non neoplastik dan membedakan glioma dengan lesi neoplastik SSP primer lainnya. Spesimen dari tumor SSP sering pula hanya berupa fragmen jaringan kecil yang menimbulkan kesulitan tersendiri dalam diagnosis.

Deteksi adanya mutasi IDH1 dan IDH2 dapat dilakukan dengan beberapa metode. Studi awal tentang mutasi IDH pada glioma menggunakan direct sequencing. Meskipun sequencing merupakan gold standard untuk deteksi mutasi IDH, telah dikembangkan alat deteksi yang lebih cepat dan lebih mudah dilakukan. Pengembangan antibodi monoklonal terhadap IDH1 R132H memungkinkan pemeriksaan adanya mutasi IDH yang paling sering terjadi pada glioma yang dapat dilakukan pada jaringan dalam blok parafin, dan metode ini paling sering dilakukan pada klinis untuk menentukan klasifikasi tumor.

Tahapan diagnosis kasus glioma difus yang saat ini dilakukan di banyak senter laboratorium patologi yaitu: 1)Evaluasi histologik untuk mengkonfirmasi asal tumor; 2)Pemeriksaan imunohistokimia IDH1 $\mathrm{R} 132 \mathrm{H}$; 3)Pemeriksaan imunohistokimia p53 dan ATRX; 4)FISH untuk memeriksa kodelesi 1p/19q; 5)Jika imunohistokimia IDH1 $\mathrm{R} 132 \mathrm{H}$ menunjukkan hasil negatif, maka dimintakan pemeriksaan sequencing mutasi IDH1/IDH2; 6)Jika histologik menunjukkan glioblastoma (grade IV), dimintakan pemeriksaan metilasi O-6methylguaninetransferase

(Gambar 2)

Saat ini terapi target yang mentarget mutasi IDH2 pada leukemia myeloid akut telah disetujui di Amerika, namun terapi target pada glioma dengan mutasi IDH1 dan IDH2 masih dalam tahap penelitian. Meski mekanisme yang mendasari muatasi IDH berperan dalam biologi tumor dan terapi target masih dalam tahap penelitian, kepentingan klinik deteksi mutasi IDH pada diagnosis glioma ini akan menentukan klasifikasi, dan stratifikasi risiko pasien. Pasien glioma grade II dan III dengan mutasi IDH memiliki angka survival yang lebih baik dibandingkan pasien tanpa mutasi IDH. ${ }^{11}$

\section{SIMPULAN}

Mutasi IDH1 dan IDH2 merupakan peristiwa onkogenik awal pada glioma derajat rendah. Mutasi ini ditemukan pada sebagian besar kasus glioma difus pada dewasa. Klasifikasi tumor SSP WHO tahun 2016 mengintegrasikan gambaran histologik dan genetik molekuler termasuk pada glioma. Integrasi ini penting dalam menentukan prognosis dan rencana terapi pada pasien. Ke depan, diperlukan banyak penelitian tentang 
mekanisme mutasi IDH dalam gliomagenesis dan biologi tumor, serta penelitian tentang terapi target yang mentarget IDH mutan sehingga meningkatkan peluang memperbaiki outcome pasien glioma.

\section{PERNYATAAN}

Penulis tidak memiliki konflik kepentingan dengan pihak lain dalam penulisan ini.

\section{DAFTAR PUSTAKA}

1. Louis DN, Perry A, Reifenberger G, dkk. The 2016 World Health Organization Classification of Tumors of the Central Nervous System: a summary. Acta Neuropathol. 2016;131:803-20.

2. Lee SC. Diffuse gliomas for nonneuropathologists: The new integrated molecular diagnostics. Arch Pathol Lab Med. 2018;142:804-14.

3. Cairns RA, Mak TW. Oncogenic isocitrate dehydrogenase mutations: Mechanisms, models, and clinical opportunities. Cancer Discov. 2013;3:730-41.

4. Maus A, Peters GJ. Glutamate and $\alpha-$ ketoglutarate: key players in glioma metabolism. Amino Acids. 2017;49:21-32.

5. Tommasini-Ghelfi S, Murnan K, Kouri
FM, dkk. Cancer-associated mutation and beyond: The emerging biology of isocitrate dehydrogenases in human disease. Sci Adv.2019;5:eaaw4543.

6. Turkalp Z, Karamchandani J, Das S. IDH mutation in glioma: New insights and promises for the future. JAMA Neurol. 2014;71:1319-25.

7. Monga V, Jones K, Chang S. Clinical Relevance Of Molecular Markers In Gliomas. Rev Médica Clínica Las Condes. 2017;28:343-51.

8. Yan H, Parsons DW, Jin G, dkk. IDH1 and IDH2 mutations in gliomas. $N$ Engl J Med. 2009;360:765-73.

9. Huang $\mathrm{J}, \mathrm{Yu} \mathrm{J}, \mathrm{Tu} \mathrm{L}, \mathrm{dkk}$. Isocitrate dehydrogenase mutations in glioma: From basic discovery to therapeutics development. Front Oncol. 2019;9:506.

10. Olar A, Wani KM, Alfaro-Munoz KD, dkk. IDH mutation status and role of WHO grade and mitotic index in overall survival in grade II-III diffuse gliomas. Acta Neuropathol.2015; 129:585-596

11. Komori T. The 2016 WHO classification of tumours of the central nervous system: The major points of revision. Neurol Med Chir (Tokyo). 2017;57:301-11. 